\title{
WORK-RELATED INTERNET USE AS A THREAT TO WORK-LIFE BALANCE - A COMPARISON BETWEEN THE EMERGING ON-LINE PROFESSIONS AND TRADITIONAL OFFICE WORK
}

\author{
ALEKSANDRA JACUKOWICZ and DOROTA MERECZ-KOT \\ Nofer Institute of Occupational Medicine, Łódź, Poland \\ Department of Health and Work Psychology
}

\begin{abstract}
Objectives: In the present study, the authors focused on the comparison of work characteristics related to the possibility of striking the right worknonwork balance, as well as satisfaction with the actual work-life balance (WLB), negative work-to-home conflict and the quality of life related to social relationships, between a new group of on-line workers (social media or e-marketing specialists, search engine optimization or search engine marketing specialists, e-public relations experts etc.) and traditional office workers. Material and Methods: The authors conducted a questionnaire study covering 189 on-line workers (whose work required permanent presence on-line) and 200 office workers (using the Internet mainly to communicate with other departments and to search for information). Results: The results showed that the on-line workers reported a significantly lower satisfaction with WLB and a higher negative work-home interaction. The authors found no differences as regards the social quality of life between the studied groups. Conclusions: These findings confirm that technology advancement opens a new chapter in organizational psychology and occupational health, especially in the context of the emerging on-line occupations. Int J Occup Med Environ Health. 2020;33(1):21-33
\end{abstract}

Key words:

quality of life, work-home interaction, work-life balance, office work, on-line work, overtime work

\section{INTRODUCTION}

\section{New types of on-line work - emerging professions}

Work-related Internet and social media use has evolved rapidly for the last few years. Modern on-line work is no longer only about telework, based on performing the conventional office work outside the typical workplace [1]. The revolution of the Internet communication has posed a new challenge for companies and employers - Internet users are free to express their opinions about services, products and companies, even if they have no experience with a particular brand. Therefore, timely reactions and up-to-date communication with the digital world have become crucial for the company's success [2,3]. The task is even more challenging considering the develop-

Funding: this research was supported by the Polish Ministry of Health (project entitled: "The National Health Programme for the years 2016-2020, coordination, evaluation and research - task 6: conducting research aimed at assessing the relationship between potential health risk factors or other risk factors and the state of health of the population," project manager: Dorota Merecz-Kot, Ph.D.).

Received: May 2, 2019. Accepted: September 3, 2019.

Corresponding author: Aleksandra Jacukowicz, Nofer Institute of Occupational Medicine, Department of Health and Work Psychology, św. Teresy 8, 91-348 Łódź, Poland (e-mail: aleksandra.jacukowicz@imp.lodz.pl). 
ment of mobile technology that allows people to access news, messages and notifications anywhere, anytime $[1,4]$. As a result, more and more companies are searching for specialists who will take care of monitoring and reacting to Internet users' behaviors on-line - on-line marketing, social media, search engine optimization (SEO), copywriting, e-public relations (e-PR) specialists etc. As a result, the volatile nature of Internet interactions makes permanent on-line presence the primary task of their work.

\section{Personal and professional use of the Internet}

The role of the Internet and social media in everyday life has been studied more and more extensively in recent years. Yet, previous studies have mainly focused on the aspects of wellbeing and health resulting from using the Internet for private purposes. Hence, the specificity of psychological demands of the emerging on-line professions requiring permanent presence on-line, and their impact on work ability as well as on mental and physical health, remain largely unknown [5-8]. On the one hand, previous studies have shown that the majority of people using the Internet for personal purposes feel that it facilitates their everyday functioning, helping them in communicating with friends and family, searching for information and entertainment, as well as conducting everyday transactions [9]. The Internet-based social interactions, in particular, might enhance the sense of social support, selfesteem and belonging [10-13]. Also, the use of social media for personal purposes, even when at work, increases workers' job satisfaction and job performance [14].

On the other hand, many researchers raise the issue of some potential threats to mental and physical health and well-being, resulting from the (excessive) Internet and social media use. For instance, relying on on-line social interactions might lead to depression and the sense of isolation since on-line relationships are argued to be poorer and less sustaining $[11,13]$. It has also been confirmed that a large amount of time spent on social network sites for private purposes when at work increases the risk of burn- out [5]. Previous research has also revealed a link between an increased use of social media and the total amount of sitting time [15], which may pose a challenge to good physical health. Constant presence on-line might also prevent individuals from focusing on work and, as a consequence, deteriorate their mental health [16].

If it comes to work-related Internet and social media use, the current research is exceptionally scarce [5-8]. Current evidence recognizes some substantial resources (e.g., access to first-hand information or feedback from the consumers or partners that increases workers' engagement) as well as excess demands (e.g., exhaustion and threat to work-life balance [WLB] due to "boundary conflicts") [8, p. 8]. The intrusion in private lives might result from the potential fear of any crisis happening as soon as one stops monitoring the Internet. As a result, an individual feels the urge to check the notifications and messages (perform work activities) also in free time. Moreover, social media and the Internet are not only work tools, but also means of entertainment and relax for many people. For instance, a Dutch study on Twitter users showed that it was common for the respondents to post personal information while at work, but also work-related news while already at home [7].

\section{Work-nonwork balance}

Work-life balance constitutes one of the crucial components of the employees' quality of life and satisfaction with work. It is understood as a satisfaction with the way individuals are capable of combining their work life with all the other spheres and roles in their life, regardless of the amount of time devoted to each sphere, as well as the proportions between the time and energy allocated to these domains [17-20]. Earlier studies in the field concentrated on the conflict between "work" and "family" [21], but the concept of the balance between work and private life has changed considerably with the "recognition of the diversity that exists in employees' pursuits outside of work" [19, p. 221]. For instance, Keeney et al. distinguished 8 differ- 
ent nonwork life domains that could be interfered by work: health, family, household, friendships, education, romantic relationships, community and leisure [19, p. 228].

Importantly, some people prefer various life domains to be clearly separated, whereas for others, it is easier to fulfill the essential life roles when their private and work spheres permeate [22,23]. Moreover, what is perceived as an individual "balance" might change over time, along with passing through different personal, professional and family stages [23]. Previous studies have shown that the vast majority of the working population experiences some degree of work-nonwork conflict [23]. Therefore, it is reasonable to consider negative as well as positive aspects of this interference, but also the quality and subjective satisfaction with the achieved balance [24,25].

A satisfactory work-nonwork balance translates into employees' personal and professional functioning. Studies provide abundant evidence that work-nonwork balance is related to a better quality of life [18,26], lower stress and depression [26]. Also, the experience of a negative as well as positive work-to-life interface might have a significant impact on the satisfaction with marriage [27]. Moreover, the possibility to fully recover after work enhances not only employees' health and well-being, but also their work engagement and proactive behavior presented at work [28]. Furthermore, WLB increases the affective organizational commitment and decreases the intention to leave [26].

Referring to the Greenhaus and Beutell theory of behavior-, time- and strain-related work-life conflict [29], Messersmith suggests that IT workers are especially prone to experience the latter 2 types of conflicts between their professional and private lives [30]. The author suggests that these are unpredictable working hours and work overload, as well as work-related stress affecting the possibility to regenerate at home, that are the main causes for a high risk of work-life imbalance in this professional group [30].

Previous studies linking technology and WLB have focused mainly on the use of technology in general and among em- ployees of various professions [31,32]. Here, the authors focused specifically on the professionals whose main task is to use the Internet to interact with (potential) customers and followers (e.g., via social media). On the one hand, it has been already evidenced that using technology at work and performing work-related activities on-line also after working hours might blur the boundaries between work and home spheres. On the other hand, in this particular profession the demand to stay on-line seems inevitable, or at least an expected part of the job. The authors assumed that undertaking work-related activities on-line after working hours based on one's own decision might have a different effect on employees than when doing this because it is a job requirement. Moreover, such work is usually performed by younger people, who are well-accustomed to using technology in nearly all life situations [33]. Therefore, there remains the question of whether WLB of such employees is impacted by the demand to use the Internet for work-related purposes also after work.

\section{Study objective}

Bearing in mind the above considerations, the authors aimed at determining whether working on-line might predict WLB (which is here depicted by the subjective satisfaction with WLB, negative work-home interaction and the social quality of life), assuming that this type of work will have an adverse impact on employees' WLB.

\section{MATERIAL AND METHODS \\ Methods}

To gather the information necessary to achieve the research goals, the authors conducted a questionnaire study using the methods presented below.

\section{Socio-demographic characteristics and functioning at work}

A survey with close-ended questions about the personal (gender, age), family (life partner, children $<18$ years) and work situation of the participants (on-line work vs. tradition- 
al office work, the number of paid working hours per week, and working overtime - here understood as "staying in the workplace after regular hours," as opposed to another variable: work-related activities in free time, e.g., finishing projects at home, planning work for the next day, additional paid work). The authors were interested in distinguishing between the time spent working in the workplace and the free time devoted to working when at home. The authors wanted to verify whether the "intrusion" of work into the private sphere impacts on the workers' WLB in a different way than overwork in the workplace does.

\section{Satisfaction with WLB}

One item with a 6-point scale of responses ranging from 0 - "not at all" to 6 - "very much" - "Considering your engagement in family life, work and other activities, to what extent are you satisfied with the way you reconcile these spheres?".

\section{Negative work-home interaction}

A subscale of the Survey Work-Home Interaction-Nijmegen (SWING) by Geurts et al. [34], in the Polish adaptation by Mościcka-Teske and Merecz-Kot [35]. The subscale includes 8 questions on various forms of a negative impact of professional life on the possibility to realize oneself in private life, for instance, being irritated by work even while at home, no energy to involve in family life because of work, or the lack of time to relax after work. The participants are asked to refer to the statements by choosing 1 option on a 4-point scale - from 0 - "never," to 3 - "always." Cronbach's $\alpha$ for the subscale $=0.89$ [35].

\section{Quality of life - the social relationships domain}

One subscale of the World Health Organization Quality of Life - BREF (WHOQOL-BREF) questionnaire [36], in the Polish translation by Baran-Furga et al. [37]. The subscale includes 3 items on the satisfaction with personal relationships with others, received social support and sexual life. The participants' task is to answer the questions by choosing 1 option on a 5-point scale, ranging from "very dissatisfied" to "very satisfied." Cronbach's $\alpha=0.73$, calculated for this study sample $(\mathrm{N}=389)$.

The study procedure received the ethics committee approval of the Nofer Institute of Occupational Medicine Bioethics Committee (decision number 12/2016 dated November 18, 2016).

\section{Recruitment method and participants}

To recruit traditional office workers, the authors turned to a few large Polish companies employing accountants, economics specialists or clerks, whereas mailing and social media posts were addressed to (on-line) marketing agencies/ specialists (for example, posted on special groups gathering such professionals). The study included 389 respondents traditional office workers $(\mathrm{N}=200)$ and on-line workers $(\mathrm{N}=189)$. "Traditional office workers" referred to those employees whose work might include using the Internet, but mainly to search for information and exchange documents between departments, rather than for communication, especially with (potential) customers on-line. On the contrary, "on-line workers" included only those employees whose work tasks required permanent presence on-line, mainly to monitor and react to Internet users' behaviors on-line.

The authors verified the nature of work of each participant in several ways. To make sure that they addressed the people performing the desired types of work, the cover letters as well as instructions in the questionnaires included information that the study was addressed to people performing office work or whose work required being on-line all the time. This was clear in all the invitations posted on social media and in mailing. Also, in the socio-demographic part, the survey included questions on the professional background of the participants. They were asked to decide which of the 2 descriptions referred to their own work: "work demanding PERMANENT presence on-line, monitoring and reacting to things happening on-line" vs. 
"traditional office work which involves using the computer and the Internet." Lastly, the authors also asked the participants to provide information on their job position, which made it possible to verify the character of their work.

\section{Analysis}

First, the authors calculated descriptive statistics, compared the distribution of responses using $\chi^{2}$ independence test and compared the means using t-tests for independent samples. Then, they performed a hierarchical linear regression. In the first step, the following control variables were introduced: gender, age, children $<18$ years, having a life partner, the number working hours per week, the frequency of overtime work and the frequency of performing work-related activities when at home. The choice of these variables was based on research evidence on the factors affecting WLB. In the second step, the authors introduced the type of work - on-line vs. traditional. They conducted 3 separate regression analyses for 3 dependent variables, i.e., satisfaction with WLB, negative work-home interference and the quality of social life. All the analyses were performed using IBM SPSS Statistics 19.

\section{RESULTS}

\section{Descriptive statistics}

The results showed some differences in the characteristics of the study samples - the group of on-line workers included significantly more women and fewer parents of children $<18$ years. A similar number of respondents in both groups declared to have life partners (Table 1). Only $23 \%$ of the studied on-line workers and $8 \%$ of traditional office workers did their work at their own home. Additionally, on-line workers were significantly younger $\left(\mathrm{M}_{1}=29.6 \pm(-5.2)\right.$, $\left.\mathrm{M}_{2}=39.2 \pm 10.6, \mathrm{t}(293.3)=11.5, \mathrm{p}<0.001\right)$.

The results also showed that on-line workers worked significantly more hours per week (including all hours of paid work) than traditional office workers $(\mathrm{t}(303.6)=-3.4$, $\mathrm{p}<0.01)$. Traditional office workers spent $41.5 \mathrm{~h} /$ week at work, on average, whereas on-line workers declared to have worked for $45.0 \mathrm{~h} /$ week, on average.

Further, the authors found no significant differences between on-line and traditional office workers as regards the frequency of overtime work in general $\left(\chi^{2}(3)=7.09, p>\right.$ $0.05)$ (self-employed persons were excluded from this analysis, $\mathrm{N}=49$ ). However, a closer look at the distribution of

Table 1. Differences in the sample characteristics between on-line and traditional office workers ( $\chi^{2}$ independence test) in the study on on-line work as a threat to work-life balance, conducted on a group of 189 on-line workers and 200 office workers

\begin{tabular}{|c|c|c|c|c|c|c|c|c|}
\hline \multirow{3}{*}{ Variable } & \multicolumn{6}{|c|}{$\begin{array}{l}\text { Participants } \\
(\mathrm{N}=389)\end{array}$} & \multirow{3}{*}{$\chi^{2}$} & \multirow{3}{*}{$\mathrm{p}$} \\
\hline & \multicolumn{2}{|c|}{ total } & \multicolumn{2}{|c|}{ traditional office workers } & \multicolumn{2}{|c|}{ on-line workers } & & \\
\hline & $\mathrm{n}$ & $\%$ & $\mathrm{n}$ & $\%$ & $\mathrm{n}$ & $\%$ & & \\
\hline Gender & & & & & & & 22.7 & $<0.001$ \\
\hline women & 275 & 71 & 120 & 60 & 155 & 82 & & \\
\hline men & 114 & 29 & 80 & 40 & 34 & 18 & & \\
\hline Children $<18$ years old & & & & & & & 18.3 & $<0.001$ \\
\hline no & 280 & 72 & 125 & 63 & 155 & 82 & & \\
\hline yes & 109 & 28 & 75 & 38 & 34 & 18 & & \\
\hline Life partner & & & & & & & 0.60 & $>0.05$ \\
\hline no & 110 & 28 & 53 & 27 & 57 & 30 & & \\
\hline yes & 279 & 72 & 147 & 74 & 132 & 70 & & \\
\hline
\end{tabular}


responses reveals that even though a similar percentage of both kinds of workers worked overtime in general, these were on-line workers who declared to do it "often" or "very often" (38\% of on-line workers vs. $25 \%$ of traditional office workers working overtime often or very often).

On the other hand, the results revealed significant differences in the number of people who admitted to performing work-related activities in their free time $\left(\chi^{2}(4)=28.8\right.$, $\mathrm{p}<0.001)$. In total, 9 out of 10 on-line workers, in comparison to $74 \%$ of traditional office workers, worked also besides their paid working hours (in their free time). The analysis revealed that $40 \%$ of on-line workers "often" performed work activities after their official working hours, and other $35 \%$ did so "very often" or "almost always."

\section{Nature of work and work-life balance}

To verify whether the nature of work (traditional office work vs. on-line work) predicts WLB, the authors conducted a series of hierarchical linear regression analyses for 3 separate dependent variables: satisfaction with the achieved WLB, negative work-home interaction and the quality of social life. In the first step, control variables were entered, including gender, age, children $<18$ years, having a life partner, as well as work-related characteristics likely to impact on WLB: the number of working hours per week, the frequency of working overtime (in the workplace) and performing working-related activities when already at home. In the second step, the potential predictor was introduced, being the nature of work (traditional office work vs. on-line work).

\section{Predictors of the negative work-home interaction}

The model in the first step was statistically significant and accounted for $37 \%$ of the variance in the negative workhome interaction. The addition of the nature of work significantly improved predictions. In this case, working online predicted a higher negative impact of work on home life $(\beta=0.16, p<0.01)$. Similarly, also older participants and those having no life partner were more likely to report a higher negative work-to-home spillover $(\beta=0.14$, $p<0.01$ and $\beta=-0.09, p<0.05$, respectively). The higher frequency of working overtime $(\beta=0.15, \mathrm{p}<0.01)$ and performing work-related activities at home $(\beta=0.48$, $\mathrm{p}<0.001)$ were also significant predictors of the negative work-home interaction, with the last being the strongest predictor. The model explained $38 \%$ of the variance in total (Table 2).

\section{Predictors of the satisfaction with work-life balance}

The model in the first step was statistically significant and accounted for $18 \%$ of the variance in the satisfaction with WLB. As hypothesized, the addition of the type of work significantly improved predictions $(\Delta \mathrm{F}=9.30, \mathrm{p}<0.01)$. The negative $\beta$ coefficient value revealed that working on-line predisposed to experiencing a lower satisfaction with WLB $(\beta=-0.17, p<0.01)$. The results also showed that having no life partner $(\beta=0.17, \mathrm{p}<0.01)$, as well as a higher frequency of working overtime $(\beta=-0.25$, $\mathrm{p}<0.001)$ and performing work-related activities at home $(\beta=-0.22, p<0.001)$ were significant predictors of the satisfaction. The model explained $20 \%$ of the variance in total (Table 3).

\section{Predictors of the quality of social life}

The first-step model was significant and explained $10 \%$ of the variance in the quality of social life. The additional variable in the second step significantly improved predictions and the final model predicted $11 \%$ of the variance ( $\mathrm{F}$ change $=7.27, \mathrm{p}<0.001)$. Beta coefficients values indicated that having no life partner could be regarded as a significant predictor of a worse quality of social life $(\beta=0.34, p<0.001)$. As hypothesized, the nature of work allowed for predicting the dependent variable also in this case, but this time working on-line predicted better indicators of WLB, being the quality of social life in this case $(\beta=0.13, p<0.05)($ Table 4$)$. 
Table 2. Hierarchical linear regression for the negative work-home interaction (SWING) in the study on on-line work as a threat to work-life balance, conducted on a group of 189 on-line workers and 200 office workers

\begin{tabular}{|c|c|c|c|c|c|c|c|c|c|c|}
\hline Step/Predictor & $\mathrm{B}$ & SE & $\beta$ & $\mathrm{t}$ & $\mathrm{p}$ & $\mathrm{F}$ & $\mathrm{p}$ & $\begin{array}{c}\text { Adjusted } \\
\mathrm{R}^{2}\end{array}$ & $\Delta \mathrm{F}$ & $\mathrm{p}$ \\
\hline Step 1 & & & & & & 32.47 & 0.000 & 0.37 & 32.47 & 0.000 \\
\hline gender & 0.89 & 0.46 & 0.08 & 1.92 & 0.055 & & & & & \\
\hline age & 0.04 & 0.02 & 0.07 & 1.58 & 0.115 & & & & & \\
\hline children $<18$ years old & -0.08 & 0.49 & -0.01 & -0.16 & 0.874 & & & & & \\
\hline life partner & -0.87 & 0.48 & -0.08 & -1.81 & 0.072 & & & & & \\
\hline working time $[\mathrm{h} /$ week $]$ & 0.05 & 0.02 & 0.10 & 2.31 & 0.021 & & & & & \\
\hline overtime work & 0.56 & 0.19 & 0.13 & 2.90 & 0.004 & & & & & \\
\hline work-related activities when at home & 2.13 & 0.18 & 0.52 & 11.54 & 0.000 & & & & & \\
\hline Step 2 & & & & & & 30.54 & 0.000 & 0.38 & 10.98 & 0.001 \\
\hline gender & 0.71 & 0.46 & 0.07 & 1.53 & 0.127 & & & & & \\
\hline age & 0.07 & 0.03 & 0.14 & 2.81 & 0.005 & & & & & \\
\hline children $<18$ years old & 0.09 & 0.49 & 0.01 & 0.18 & 0.854 & & & & & \\
\hline life partner & -1.02 & 0.48 & -0.09 & -2.14 & 0.033 & & & & & \\
\hline working time [h/week] & 0.03 & 0.02 & 0.07 & 1.74 & 0.083 & & & & & \\
\hline overtime work & 0.65 & 0.19 & 0.15 & 3.40 & 0.001 & & & & & \\
\hline work-related activities when at home & 1.99 & 0.19 & 0.48 & 10.64 & 0.000 & & & & & \\
\hline type of work & 1.59 & 0.48 & 0.16 & 3.31 & 0.001 & & & & & \\
\hline
\end{tabular}

Gender: 0 - men, 1 - women; children < 18 years old: 0 - no, 1 - yes; life partner: 0 - no, 1 - yes; type of work: 1 - traditional office work, 2 - on-line work.

\section{DISCUSSION}

The presented study showed that on-line work had a small, but negative, impact on the possibility to achieve WLB, namely the satisfaction with WLB and the negative workhome interaction. Contrary to the authors' expectations, on-line work facilitated a better quality of social life.

First, this study indicated that on-line work increased the risk of a greater negative work-home interaction. It seems that, apart from longer working hours, it is also work engagement, or being absorbed and burdened with work, that might determine the possibility to gain satisfaction with one's WLB. The requirement (and/or the need) to monitor and react to people's behaviors on-line might refer to the phenomenon of the fear of missing out (FoMO) - the need to follow what others are doing all the time [38,39]. Previous studies have revealed that FoMO directly re- lates to mental and physical health. For instance, Polish researchers showed that people expressing higher FoMO felt a lower life satisfaction [40]. As argued by the authors, this lower life satisfaction might result from the increased stress imposed by a heavy emotional and cognitive burden related to the constant inner pressure to know what others are doing [40]. Similarly, a study on professionals using social media for work showed that this nature of work increased the experienced work-life conflict [41], and further, that even though this led to greater engagement, it also drove people to exhaustion [8].

Further, the study proved that on-line work predisposed to a lower satisfaction with the capability to reconcile work and private life. Such result is supported by some earlier findings - for instance, previous researchers have found that the more time devoted to receiving and replying to 
Table 3. Hierarchical linear regression for the satisfaction with work-life balance in the study on on-line work as a threat to work-life balance, conducted on a group of 189 on-line workers and 200 office workers

\begin{tabular}{|c|c|c|c|c|c|c|c|c|c|c|}
\hline Step/Predictor & $\mathrm{B}$ & SE & $\beta$ & $\mathrm{t}$ & $\mathrm{p}$ & $\mathrm{F}$ & $\mathrm{p}$ & $\begin{array}{c}\text { Adjusted } \\
\mathrm{R}^{2}\end{array}$ & $\Delta \mathrm{F}$ & $\mathrm{p}$ \\
\hline Step 1 & & & & & & 12.79 & 0.000 & 0.18 & 12.79 & 0.000 \\
\hline gender & 0.03 & 0.14 & 0.01 & 0.18 & 0.857 & & & & & \\
\hline age & 0.00 & 0.01 & -0.01 & -0.12 & 0.905 & & & & & \\
\hline children $<18$ years old & -0.06 & 0.15 & -0.02 & -0.38 & 0.707 & & & & & \\
\hline life partner & 0.46 & 0.15 & 0.16 & 3.10 & 0.002 & & & & & \\
\hline working time $[\mathrm{h} /$ week $]$ & -0.01 & 0.01 & -0.05 & -1.06 & 0.290 & & & & & \\
\hline overtime work & -0.26 & 0.06 & -0.22 & -4.45 & 0.000 & & & & & \\
\hline work-related activities when at home & -0.28 & 0.06 & -0.25 & -4.95 & 0.000 & & & & & \\
\hline Step 2 & & & & & & 12.60 & 0.000 & 0.20 & 9.30 & 0.002 \\
\hline gender & 0.08 & 0.14 & 0.03 & 0.55 & 0.581 & & & & & \\
\hline age & -0.01 & 0.01 & -0.08 & -1.35 & 0.177 & & & & & \\
\hline children $<18$ years old & -0.10 & 0.15 & -0.04 & -0.70 & 0.487 & & & & & \\
\hline life partner & 0.50 & 0.15 & 0.17 & 3.41 & 0.001 & & & & & \\
\hline working [h/week] & 0.00 & 0.01 & -0.03 & -0.53 & 0.595 & & & & & \\
\hline overtime work & -0.29 & 0.06 & -0.25 & -4.91 & 0.000 & & & & & \\
\hline work-related activities when at home & -0.24 & 0.06 & -0.22 & -4.19 & 0.000 & & & & & \\
\hline type of work & -0.45 & 0.15 & -0.17 & -3.05 & 0.002 & & & & & \\
\hline
\end{tabular}

Explanations as in Table 2.

work-related electronic communication besides working hours, the greater the perceived work-life conflict experienced by the studied workers [42], and the higher the risk of having family problems, such as issues related to marriage, children or elderly family members [43]. It is possible that the on-line workers whose work demands monitoring the Internet users' behaviors might experience the negative consequences of what is particularly apparent in their case - the issue of blurred boundaries between home and working time.

What is particularly alarming in this case is the frequency of engaging in work-related activities in nonwork time among on-line workers that was shown in the results of this study. Researchers underline the role of detachment from work for employees' well-being, including a higher life satisfaction and lower emotional exhaustion [44].
Similarly, the work-related Internet use besides working hours has previously been evidenced to increase the risk of family problems [43]. As a result, the integration of work and private spheres, manifested in performing some family-related activities when at work and work-related tasks besides working hours is assumed to improve individual's work performance, while deteriorating family engagement or satisfaction [45].

Considering the total amount of time and engagement related to work, the authors found it surprising that online work increased the quality of life related to social relationships. Possibly, on-line workers may satisfy their need for social interactions via Internet contacts that, at least partially, could be realized also during working hours. Permanent access to the Internet and social media might enhance maintaining relationships with friends and 
Table 4. Hierarchical linear regression for the quality of social life in the study on on-line work as a threat to work-life balance, conducted on a group of 189 on-line workers and 200 office workers

\begin{tabular}{|c|c|c|c|c|c|c|c|c|c|c|}
\hline Step/Predictor & B & SE & $\beta$ & $\mathrm{t}$ & $\mathrm{p}$ & $\mathrm{F}$ & $\mathrm{p}$ & $\begin{array}{c}\text { Adjusted } \\
\mathrm{R}^{2}\end{array}$ & $\Delta \mathrm{F}$ & $\mathrm{p}$ \\
\hline Step 1 & & & & & & 7.27 & 0.000 & 0.10 & 7.27 & 0.000 \\
\hline gender & -0.26 & 0.37 & -0.04 & -0.71 & 0.478 & & & & & \\
\hline age & -0.01 & 0.02 & -0.02 & -0.30 & 0.765 & & & & & \\
\hline children $<18$ years old & -0.34 & 0.40 & -0.05 & -0.86 & 0.392 & & & & & \\
\hline life partner & 2.50 & 0.39 & 0.35 & 6.49 & 0.000 & & & & & \\
\hline working time $[\mathrm{h} /$ week] & 0.01 & 0.02 & 0.02 & 0.41 & 0.684 & & & & & \\
\hline overtime work & -0.15 & 0.15 & -0.05 & -0.97 & 0.333 & & & & & \\
\hline work-related activities when at home & -0.20 & 0.15 & -0.07 & -1.34 & 0.182 & & & & & \\
\hline Step 2 & & & & & & 6.98 & 0.000 & 0.11 & 4.49 & 0.035 \\
\hline gender & -0.36 & 0.37 & -0.05 & -0.97 & 0.333 & & & & & \\
\hline age & 0.01 & 0.02 & 0.04 & 0.58 & 0.559 & & & & & \\
\hline children $<18$ years old & -0.25 & 0.40 & -0.03 & -0.64 & 0.520 & & & & & \\
\hline life partner & 2.42 & 0.39 & 0.34 & 6.29 & 0.000 & & & & & \\
\hline working time [h/week] & 0.00 & 0.02 & 0.00 & 0.04 & 0.968 & & & & & \\
\hline overtime work & -0.10 & 0.15 & -0.03 & -0.65 & 0.518 & & & & & \\
\hline work-related activities when at home & -0.27 & 0.15 & -0.10 & -1.79 & 0.075 & & & & & \\
\hline type of work & 0.82 & 0.39 & 0.13 & 2.12 & 0.035 & & & & & \\
\hline
\end{tabular}

Explanations as in Table 2.

family, even though it is done via virtual reality. Previous studies have provided similar findings, showing positive relationships between the use of social media and perceived social support $[11-13,46]$. Thus, despite the blurred lines between private and working time, on-line workers might have more freedom to maintain their social contacts whenever they need to, not only in their free time. Moreover, since on-line workers were less likely to have children aged $<18$ years than the studied traditional office workers, it might have been easier for them to find the time to meet friends or engage in social life than it was for working parents.

Additionally, the obtained results revealed that the average number of paid hours per week, both in the case of traditional office as well as on-line workers, exceeded the typical full-time $40 \mathrm{~h}$, and it was even higher for on-line workers. Similar results were offered in a large analysis of working hours across Europe - 27\% of male and 22\% of female workers from Eastern Europe (including Poland) worked $41-50 \mathrm{~h}$ on average and these were the highest indicators in comparison to other European regions [47]. Previous studies have shown that longer working hours or performing work while at home, and besides paid working hours, might bring negative consequences for workers' well-being, health as well as the quality of life. For instance, working moderately long hours $(41-50 \mathrm{~h})$ predicted poor self-assessed health among men from Eastern European countries [47]. Similarly, a large European study showed that the level of the perceived stress increased with the number of hours worked per week, both among men and women. Stress was also positively related to performing overtime, evening and weekend work [48]. 


\section{Limitations}

The conclusions from this study are somewhat limited, due to the lack of control over dropouts. As on-line specialists were recruited via social media, the authors were unable to control the demographics of those who did not respond to their invitation. Thus, some bias in the results could have appeared. The direction of this bias is speculative: either the topic of the study was not the issue for non-respondents - a possibility to obtain an even smaller effect in the regression models, or those who did not respond were overwhelmed with work and did not have time to participate - a possibility to obtain stronger effects in the regression models. Nevertheless, future research aimed at studying the predictors of WLB in new on-line professions should be performed in larger groups with restricted control for dropouts. It would also be valuable to conduct cohort studies on these phenomena to follow the relationship between the type of job, WLB and wellbeing of employees working on-line. Nevertheless, future research should aim at comparing the professional groups of more similar age, since previous studies have suggested that WLB might be affected by the worker's age [9].

The above research focused on work-home interference, whereas it would also be worth verifying the impact of private life on the possibilities to perform on-line work (for example, when working from home is needed). Last but not least, working with a (potential) client via the Internet (an Internet user) is more similar to work in customer service than to a traditional office work. Thus, future research should also aim at comparing representatives of different office and on-line professions so as to achieve a more detailed insight and a better understanding of the potential similarities and differences between the studied groups.

\section{CONCLUSIONS}

The presented study reveals that the modern on-line workers whose work requires permanent monitoring and reacting to Internet users' behaviors on-line might experience more problems with striking the right work-nonwork balance. In the era of the growing need for satisfactory reconciliation of work and all the other spheres of life [50,51], the issue of increasing the awareness of, and supporting young professionals in achieving, the right WLB becomes of cardinal importance. In the case of emerging on-line professions, it is not possible to implement the protective and preventive measures usually offered by traditional health and safety procedures. Thus, it appears indispensable to find new ways of protecting employees' well-being at work.

For instance, the results of this study reveal 2 domains requiring management and HR departments' attention a lower satisfaction with the way workers reconcile their work and life spheres, and a greater negative impact of work on private life than it is observed among "traditional" office workers. Numerous studies have evidenced the effectiveness of family-friendly policies including, for instance, WLB benefits $[30,52,53]$. Such benefits as flexible working hours, a task-based system, telework, support in organizing care for their children (e.g., company kindergartens) and flexibility as regards leaves (especially in unexpected situations like the child's illness) might significantly help employees achieve the desired WLB.

It is also worth noting that the liaison between modern online employees and their employers is completely different from what it once was. Employers are no longer the only ones responsible for working conditions; therefore, online employees should be trained in how to organize their work to protect themselves against the negative impact of psychosocial and ergonomic risks [54]. For instance, Duxbury and Smart suggest increasing the sense of WLB by enhancing the person-environment fit. The authors underline the potential of the cooperation between an organization and its employees in terms of communicating needs and expectations as regards work-life integration, as well as taking an individual approach to an employee [54]. In their thought-provoking paper on the future of work and WLB, Khallash and Kruse state that in the nearest 
future more and more jobs will offer the possibility to work from wherever one wants [55]. This, on the one hand, will further enhance flexibility but, on the other, it might pose an even greater challenge to what is now understood as WLB [55]. It is obvious that technology advancement opens a new chapter in organizational psychology and occupational health, requiring that both the definition of work environment, and the aims and tasks of health protection in the workplace, be reformulated.

\section{REFERENCES}

1. Bailey DE, Kurland NB. A review of telework research: findings, new directions, and lessons for the study of modern work. J Org Beh. 2002;23(4):383-400, https://doi.org/10.1002/job.144.

2. Hanna R, Rohm A, Crittenden VL. We're all connected: The power of the social media ecosystem. Bus Horiz. 2011;54(3): 265-73, https://doi.org/10.1016/j.bushor.2011.01.007.

3. Xu WW, Feng M. Talking to the Broadcasters on Twitter: Networked Gatekeeping in Twitter Conversations with Journalists. J Broadcast Electron Media. 2014;58(3):420-37, https:// doi.org/10.1080/08838151.2014.935853.

4. Venkatesh R, Jayasingh S. Transformation of business through social media. In: Rao R, editor. Social Media Listening and Monitoring for Buisness Applications. IGI Global; 2016. p. 1. 5. Charoensukmongkol P, Moqbel M, Gutierrez-Wirsching S, Sanchez AR Jr. Social media sites use intensity and job burnout among the U.S. and Thai employees. Int J Cyber Behav Psychol Learn. 2017;7(1):34-51, https://doi.org/10.4018/IJCB PL.2017010103.

6. Kou Y, Gray C, Toombs A, Adams R. Knowledge Production and Social Roles in an Online Community of Emerging Occupation: A Study of User Experience Practitioners on Reddit. 2018 51th Hawaii Int Conf Syst Sci. 2018;(September 2017), https://doi.org/10125/50148.

7. Van Zoonen W, Verhoeven JWM, Vliegenthart R. How employees use Twitter to talk about work: A typology of work-related tweets. Comput Human Behav. 2016;55:329-39, https:// doi.org/10.1016/j.chb.2015.09.021.
8. Van Zoonen W, Verhoeven JWM, Vliegenthart R. Understanding the consequences of public social media use for work. Eur Manag J. 2017;35(5):595-605, https://doi.org/ 11245.1/6a9a818e-e4f2-420b-94ed-e4d5ce31dc17.

9. Fallows D. The Internet and daily life: Many Americans Use the Internet in Everyday Activities, but Traditional Offline Habits Still Dominate. Washington: Pew Internet \& American Life Project; 2004. p. 1.

10. Bakardjieva M, Smith R. The Internet in Everyday Life: Computer Networking from the Standpoint of the Domestic User. New Media Soc. 2001;3(1):67-83, https://doi.org/10.11 77/1461444801003001005.

11. Best P, Manktelow R, Taylor B. Online communication, social media and adolescent wellbeing: A systematic narrative review. Child Youth Serv Rev. 2014;41:27-36.

12. Kim H. Enacted social support on social media and subjective well-being. Int J Commun. 2014;8(1):2201-21, https:// doi.org/1932-8036/20140005.

13. Leung L, Lee PSN. Multiple determinants of life quality: The roles of Internet activities, use of new media, social support, and leisure activities. Telemat Informatics. 2005;22(3): 161-80, https://doi.org/10.1016/j.tele.2004.04.003.

14. Charoensukmongkol P. Effects of support and job demands on social media use and work outcomes. Comput Human Behav. 2014;36:340-9, https://doi.org/10.1016/j.chb.2014.03.061.

15. Alley S, Wellens P, Schoeppe S, de Vries H, Rebar AL, Short CE, et al. Impact of increasing social media use on sitting time and body mass index. Heal Promot J Aust Off J Aust Assoc Heal Promot Prof. 2016;28(2):91-5, https://doi. org/10.1071/HE16026.

16. Walat W. [„Homo interneticus” - wyzwanie dla współczesnej edukacji.] Eduk - Tech - Inform. 2016;18(4):235-42. Polish.

17. Clark SC. Work/Family Border Theory: A New Theory of Work/Family Balance. Hum Relations. 2000;53(6):747-70, https://doi.org/10.1177/0018726700536001.

18. Greenhaus J, Collins KM. The relation between work - family balance and quality of life. J Vocat Behav. 2003;63:51031, https://doi.org/10.1016/S0001-8791(02)00042-8. 
19. Keeney J, Boyd EM, Sinha R, Westring AF, Ryan AM. From "work-family" to "work-life": Broadening our conceptualization and measurement. J Vocat Behav. 2013;82(3):221-37.

20. Thompson JA, Bunderson JS. Work-Nonwork Conflict and the Phenomenology of Time: Beyond the Balance Metaphor. Work Occup. 2001;28(1):17-39.

21. Greenhaus JH, Beutell NJ. Sources of Conflict Between Work and Family Roles. Acad Manag Rev. 1985;10(1):76-88.

22. Olson-Buchanan JB, Boswell WR. Blurring boundaries: Correlates of integration and segmentation between work and nonwork. J Vocat Behav. 2006;68(3):432-45, https://doi. org/10.1016/j.jvb.2005.10.006.

23. Schieman S, Glavin P, Milkie MA. When Work Interferes with Life: Work-Nonwork Interference and the Influence of Work-Related Demands and Resources. Am Sociol Rev. 2009;74(6):966-88.

24. Grzywacz JG, Marks NF. Reconceptualizing the work-family interface: An ecological perspective on the correlates of positive and negative spillover between work and family. J Occup Health Psychol. 2000;5(1):111-26, https://doi.org/10. 1037/1076-8998.5.1.111.

25. Kinnunen U, Feldt T, Geurts S, Pulkkinen L. Types of workfamily interface: Well-being correlates of negative and positive spillover between work and family. Scand J Psychol. 2006;47(2):149-62, https://doi.org/10.1111/j.1467-9450.2006. 00502.x.

26. Odle-Dusseau HN, Britt TW, Bobko P. Work-Family Balance, Well-Being, and Organizational Outcomes: Investigating Actual Versus Desired Work/Family Time Discrepancies. J Bus Psychol. 2012;27(3):331-43.

27. Yucel D, Minnotte KL. Workplace Support and Life Satisfaction: the Mediating Roles of Work-to-Family Conflict and Mental Health. Appl Res Qual Life. 2017;12(3):549-75, https://doi.org/10.1007/s11482-016-9476-5.

28. Sonnentag S. Recovery, work engagement, and proactive behavior: A new look at the interface between nonwork and work. J Appl Psychol. 2003;88(3):518-28, https://doi. org/10.1037/0021-9010.88.3.518.
29. Greenhaus JH, Beutell NJ. Sources of Conflict Between Work and Family Roles. Acad Manag Rev. 1985;10(1):76-88.

30. Messersmith J. Managing work-life conflict among information technology workers. Hum Resour Manage. 2007;46(3):429-51, https://doi.org/10.1002/hrm.20172.

31. Stawarz K, Bird J, Cox AL, Benedyk R. "I'd Sit at Home and Do Work Emails": How Tablets Affect the Work-Life Balance of Office Workers. CHI'13 Ext Abstr Hum Factors Comput Syst. 2013;1383-8, https://doi.org/10.1145/2468356.2468603.

32. Butts MM, Becker WJ, Boswell WR. Hot buttons and time sinks: The effects of electronic communication during nonwork time on emotions and work-nonwork conflict. Acad Manag J. 2015;58(3):763-88, https://doi.org/10.5465/ amj.2014.0170.

33. Haeger DL, Lingham T. A trend toward Work-Life Fusion: A multi-generational shift in technology use at work. Technol Forecast Soc Change. 2014;89:316-25, https://doi. org/10.1016/j.techfore.2014.08.009.

34. Geurts SAE, Taris TW, Kompier MAJ, Dikkers JSE, Van Hooff MLM, Kinnunen UM. Work-home interaction from a work psychological perspective: Development and validation of a new questionnaire, the SWING. Work Stress. 2005;19(4):319-39, https://doi.org/10.1080/02678370 500410208 .

35. Mościcka-Teske A, Merecz D. [Polish adaptation of SWING questionnaire (Survey Work-Home Interaction - Nijmegen). Med Pr. 2012;63(3):355-69. Polish.

36. THE WHOQOL GROUP. Development of the World Health Organization WHOQOL-BREF quality of life assessment. The WHOQOL Group. Psychol Med. 1998;28:551-8.

37. World Health Organization. The World Health Organization Quality of Life (WHOQoL) - BREF. The Organization; 2004.

38. Przybylski AK, Murayama K, Dehaan CR, Gladwell V. Motivational, emotional, and behavioral correlates of fear of missing out. Comput Human Behav. 2013;29(4):1841-8.

39. Reagle J. Following the Joneses: FOMO and conspicuous sociality. First Monday. 2015;20(10), https://doi.org/10.5210/ fm.v20i10.6064. 
40. Błachnio A, Przepiórka A. Facebook intrusion, fear of missing out, narcissism, and life satisfaction: a cross-sectional study. Psychiatry Res. 2017;259(1):514-9, https://doi. org/10.1016/j.psychres.2017.11.012.

41. Van Zoonen W, Verhoeven JWM, Vliegenthart R. Social media's dark side: inducing boundary conflicts. J Manag Psychol. 2016;31(8):1297-311, https://doi.org/10.1108/JMP10-2015-0388.

42. Butts MM, Becker WJ, Boswell WR. Hot buttons and time sinks: The effects of electronic communication during nonwork time on emotions and work-nonwork conflict. Acad Manag J. 2015;58(3):763-88, https://doi.org/10.5465/ amj.2014.0170.

43. Wilczyńska A. Work-family balance of knowledge workers in Poland. Mediterr J Soc Sci. 2014;5(22):292-302, https://doi. org/10.5901/mjss.2014.v5n22p292.

44. Fritz C, Yankelevich M, Zarubin A, Barger P. Happy, healthy, and productive: The role of detachment from work during nonwork time. J Appl Psychol. 2010;95(5):977-83, https://doi.org/10.1037/a0019462.

45. Peng AC, Ilies R, Dimotakis N. Work-family balance, role integration and employee well-being. In: Kaiser S, Ringlstetter M, Eikhof D, Pina e Cunha M, editors. Creating Balance? Berlin, Heidelberg: Springer; 2011. p. 121-40. https:// doi.org/10.1007/978-3-642-16199-5_7.

46. Utz S, Breuer J. The Relationship Between Use of Social Network Sites, Online Social Support, and Well-Being. J Media Psychol. 2017;29(3):115-25, https://doi.org/10.1027/18641105/a000222.

47. Artazcoz L, Cortès I, Benavides FG, Escribà-Agüir V, Bartoll $\mathrm{X}$, Vargas $\mathrm{H}$, et al. Long working hours and health in Europe: Gender and welfare state differences in a context of economic crisis. Heal Place. 2016;40:161-8, https://doi. org/10.1016/j.healthplace.2016.06.004.

48. Costa G, Akerstedt T, Nachreiner F, Baltieri F, Carvalhais J, Folkard S, et al. Flexible working hours, health, and well-being in Europe: some considerations from a SALTSA project. Chronobiol Int. 2004;21(6):831-44, https://doi.org/10.1081/ CBI-200035935.

49. Richert-Kaźmierska A, Stankiewicz K. Work-life balance: Does age matter? Work. 2016;55(3):679-88.

50. Smith KT. Work-life balance perspectives of marketing professionals in generation Y. Serv Mark Q. 2010;31(4):434-47.

51. Choi E, Kim J. The association between work-life balance and health status among Korean workers. Work. 2017;58(4):509-17, https://doi.org/10.3233/WOR-172641.

52. Andysz A, Jacukowicz A, Stańczak A. Availability and the use of work-life balance benefits guaranteed by the Polish Labour Code among workers employed on the basis of employment contracts in small and medium enterprises. Int J Occup Med Environ Health. 2016;29(4):709-17, https://doi. org/10.13075/ijomeh.1896.00745.

53. Andysz A, Najder A, Merecz-Kot D. [Organizational and individual determinants of using initiatives conducive to successful work-life balance]. Med Pr. 2014;65(1):119-29, https://doi.org/10.13075/mp.5893.2014.012. Polish.

54. Duxbury L, Smart R. The "Myth of Separate Worlds": An Exploration of How Mobile Technology has Redefined WorkLife Balance. In: Kaiser S, Ringlstetter M, Eikhof D, Pina e Cunha M, editors. Creating Balance? Berlin, Heidelberg: Springer; 2011. https://doi.org/10.1007/978-3-642-16199-5_15.

55. Khallash S, Kruse M. The Future of Work and WorkLife Balance 2025. Futures 2012;44:678-86, https://doi. org/10.1016/j.futures.2012.04.007.

This work is available in Open Access model and licensed under a Creative Commons Attribution-NonCommercial 3.0 Poland License - http://creativecommons.org/ licenses/by-nc/3.0/pl/deed.en. 